\title{
PENGARUH PERSEPSI KEMUDAHAN PENGGUNAAN, KEPERCAYAAN, KECEMASAN BERKOMPUTER DAN KUALITAS LAYANAN TERHADAP MINAT MENGGUNAKAN INTERNET BANKING
}

$\underline{\text { Brian Dwi Saputro }}{ }^{1}$

brewsbre@gmail.com

$\underline{\text { Sukirno }^{2}}$

Fakultas Ekonomi Universitas Negeri Yogyakarta

\begin{abstract}
ABSTRAK
Penelitian ini bertujuan (1) untuk mengetahui pengaruh Persepsi Kemudahan Penggunaan terhadap Minat Menggunakan Internet Banking, (2) untuk mengetahui pengaruh Kepercayaan terhadap Minat Menggunakan Internet Banking, (3) untuk mengetahui pengaruh Kecemasan Berkomputer terhadap Minat Menggunakan Internet Banking, (4) untuk mengetahui pengaruh Kualitas Layanan terhadap Minat Menggunakan Internet Banking, (5) untuk mengetahui pengaruh Percieved Kemudahan Penggunaan, Kepercayaan, Kecemasan Berkomputer, dan Kualitas Layanan terhadap Minat Menggunakan Internet Banking. Penelitian ini merupakan penelitian asosiatif terhadap Nasabah Bank Mandiri cabang Yogyakarta. Alat uji dengan menggunakan uji prasyarat analisis yang meliputi uji normalitas, uji linearitas dan uji asumsi klasik yang meliputi uji multikolinieritas dan uji heterokedastisitas. Hasilnya menunjukkan bahwa (1) terdapat pengaruh positif dan signifikan pada Persepsi Kemudahan Penggunaan terhadap Minat Menggunakan Internet Banking dengan koefisien $\mathrm{R}$ sebesar 0,352 dan nilai t hitung sebesar 11,986 > t tabel 1,960 pada taraf signifikansi 5\%. (2) Terdapat pengaruh positif dan signifikan pada Kepercayaan terhadap Minat Menggunakan Internet Banking dengan koefisien $\mathrm{R}$ sebesar 0,385 dan nilai t hitung sebesar 8,282 > t tabel 1,960 pada taraf signifikansi 5\%. (3) Terdapat pengaruh positif dan signifikan pada Kecemasan Berkomputer terhadap Minat Menggunakan Internet Banking dengan koefisien $\mathrm{R}$ sebesar 0,615 dan nilai t hitung sebesar 8,353 > t tabel 1,960 pada taraf signifikansi 5\%. (4) Terdapat pengaruh positif dan signifikan pada Kualitas Layanan terhadap Minat Menggunakan Internet Banking dengan koefisien $\mathrm{R}$ sebesar 0,268 dan nilai t hitung sebesar 8,489 > t tabel 1,960 pada taraf signifikansi 5\%. (5) Terdapat pengaruh positif dan signifikan pada Persepsi Kemudahan Penggunaan, Kepercayaan, Kualitas Layanan terhadap Minat Menggunakan Internet Banking. Tetapi terdapat pengaruh negatif pada Kecemasan Berkomputer nilai koefisien R sebesar 0,740 dan nilai $\mathrm{F}$ hitung sebesar 40,566 > nilai $\mathrm{F}$ tabel sebesar 2,670.
\end{abstract}

Kata kunci: Internet Banking, Persepsi Kemudahan Penggunaan, Kepercayaan, Kecemasan Berkomputer, Kualitas Layanan

\footnotetext{
${ }^{1}$ Alumni Prodi Akuntansi Fakultas Ekonomi Universitas Negeri Yogyakarta

${ }^{2}$ Staf Pengajar Jurusan P. Akuntansi Fakultas Ekononi Universitas Negeri Yogyakarta
} 


\begin{abstract}
This study aimed (1) to determine the influence on the intention of use the Internet Banking, (2) to determine the effect of reliance on the intention of use the Internet Banking, (3) to determine the influence on Interests Computer Anxiety on the intention of use the Internet Banking, (4) to determine the effect of using Quality of Service on the intention of use the Internet Banking, (5) to determine the effect of Ease of Use, Trust, Computer Anxiety, and Quality of Service for the intention of use the Internet Banking. This study is associative to the Customer of Bank Mandiri that branch in Yogyakarta. This test by using test tool requirements analysis covering normality test, linearity test and classical assumption test that covers multicollinearity test and heterocedastisity test. The results show that (1) there is a positive and significant impact on the Ease of Use of the intention of use the Internet Banking with the coefficient $R$ of 0.352 and $t$ value of 11.986> t table 1.960 at significance level of 5\%. (2) There is a positive and significant impact on the confidence of the intention of use the Internet Banking with coefficient $R$ of 0.385 and $t$ value of $8.282>t$ table 1.960 at significance level of 5\%. (3) There is a positive and significant effect on the interest Computer Anxiety of the intention of use the Internet Banking with coefficient $R$ of 0.615 and $t$ value of $8.353>t$ table 1.960 at significance level of 5\%. (4) There is a positive and significant impact on the Quality of Service to the intention of use the Internet Banking with coefficient $R$ of 0.268 and $t$ value of 8.489> t table 1.960 at significance level of 5\%. (5) There is a positive and significant impact on Ease of Use, Trust, Quality of Service for Using Internet Banking Interests. But there are negative effects on Computer Anxiety with coefficient $R$ of 0.740 and $F$ value of 40.566 count $>F$ table value of 2.670 .
\end{abstract}

Keywords: Internet Banking, Percieved Ease of Use, Trust, Computer Anxiety, Services Quality

\title{
A. PENDAhULUAN
}

\section{Latar Belakang Penelitian}

Perkembangan teknologi informasi, telekomunikasi, dan internet menyebabkan mulai munculnya aplikasi bisnis yang berbasis internet. Salah satu aplikasi yang mulai mendapat perhatian adalah internet banking. Internet banking adalah salah satu pelayanan jasa bank yang memungkinkan nasabah untuk memperoleh informasi, melakukan komunikasi dan melakukan transaksi perbankan melalui jaringan internet dan bukan merupakan bank yang hanya menyelenggarakan layanan perbankan melalui internet (Tampubolon, 2004). Internet banking membuka paradigma baru, struktur baru dan strategi yang baru bagi retail bank, dimana bank menghadapi kesempatan dan tantangan yang baru (Mukherjee dan Nath, 2003).

Internet banking memberikan keuntungan bagi nasabah maupun bank. Bagi nasabah, internet banking menawarkan kemudahan dan kecepatan dalam 
melakukan transaksi perbankan. Keuntungan dari menyediakan layanan internet banking bagi bank adalah internet banking bisa menjadi solusi murah pengembangan infrastruktur dibanding membuka outlet ATM (Automated Teller Machine).

Seringkali kepercayaan akan menggunakan teknologi informasi sangat kecil dikarenakan banyaknya kejahatan online atau yang sering sekali yang disebut cyber crime yang membuat trauma para pengguna layanan internet banking ini (Gilang Rizky Amijaya, 2010). Kejadian yang terjadi pada Bank BCA yang sangat menggemparkan dunia perbankan menjadikan minat nasabah akan menggunakan layanan internet banking turun, ketakutan akan kejahatan yang sama akan terjadi pada Bank Mandiri juga.

Pihak bank mengeluarkan investasi yang tidak sedikit dalam pengembangan intenet banking guna melayani para nasabahnya, namun tetap layanan belum terlalu diminati oleh nasabah apalagi dengan tingginya tingkat resiko untuk bertransaksi online sehingga pihak bank harus meyakinkan para nasabah mereka akan kehandalan dan keamanan sistem informasi dari internet banking yang mereka miliki. Berdasarkan latar belakang di atas, maka penulis melakukan penelitian mengenai "Pengaruh Persepsi Kemudahan Penggunaan, Kepercayaan, Kecemasan Berkomputer, dan Kualitas Layanan Terhadap Minat Nasabah Bank Mandiri Menggunakan Internet Banking".

\section{Tujuan Penelitian}

Tujuan penelitian ini adalah untuk mengetahui pengaruh kemudahan penggunaan terhadap minat dalam melakukan transaksi menggunakan internet banking Mandiri pada nasabah Bank Mandiri, pengaruh kepercayaan terhadap minat dalam melakukan transaksi menggunakan internet banking Mandiri pada nasabah Bank Mandiri, pengaruh kecemasan berkomputer terhadap minat dalam melakukan transaksi menggunakan internet banking Mandiri pada nasabah Bank Mandiri, pengaruh kualitas pelayanan terhadap minat dalam melakukan transaksi menggunakan internet banking Mandiri pada nasabah Bank Mandiri, pengaruh kemudahan penggunaan, kepercayaan, kecemasan berkomputer dan kualitas layanan terhadap minat dalam melakukan transaksi menggunakan internet banking pada nasabah Bank Mandiri. 


\section{B. KAJIAN LITERATUR}

Persepsi kemudahaan penggunaan (perceived ease of use) didefinisikan sebagai sejauh mana sesorang percaya bahwa menggunakan suatu teknologi akan bebas dari usaha (Jogiyanto, 2007:115). Persepsi individu berkaitan dengan kemudahan dalam menggunakan komputer (perceived ease of use) merupakan tingkat dimana individu percaya bahwa menggunakan sistem tertentu akan bebas dari kesalahan. Persepsi ini kemudian akan berdampak pada perilaku, yaitu semakin tinggi persepsi seseorang tentang kemudahan menggunakan sistem, semakin tinggi pula tingkat pemanfaatan teknologi informasi (Igbaria, 2000).

Kepercayaan (trust) tidak begitu saja dapat diakui oleh pihak lain, melainkan harus dibangun mulai dari awal dan dapat dibuktikan. Jika suatu kepercayaan dapat terjadi di antara kedua pihak yang bersangkutan, maka hal tersebut dapat dengan mudah meningkatkan minat para pemakai dalam hal ini nasabah. Jika seorang konsumen dapat percaya dan yakin akan suatu kinerja sebuah sistem baik, maka konsumen akan menggunakan dan menganggap sebuah sistem tersebut akan menghasilkan hasil yang positif bagi para penggunanya.

Kecemasan berkomputer (computer anxiety) merupakan kecenderungan seseorang untuk menjadi susah, khawatir, atau ketakutan mengenai penggunaan komputer di masa sekarang atau di masa yang akan datang (Igbaria dan Parasuraman, 1998). Setiap individu yang bersikap positif terhadap kehadiran teknologi komputer, jika mereka merasakan manfaat teknologi informasi (TI) untuk meningkatkan kinerja dan produktivitas. Setiap individu yang mengalami kegelisahan terhadap komputer (computer anxiety) akan merasakan manfaat komputer yang lebih sedikit dibandingkan dengan mereka yang tidak mengalami kegelisahan terhadap kehadiran komputer.

Kegelisahan dan ketakutan seseorang terhadap kehadiran teknologi baru umumnya akan mendorong sikap negatif untuk menolak penggunaan teknologi informasi. Kegelisahan dan ketakutan seseorang terhadap kehadiran teknologi baru umumnya akan mendorong sikap negatif untuk menolak penggunaan teknologi informasi dalam hal ini minat dalam menggunakan internet banking dalam setiap transaksinya. 


\section{JURNAL NOMINAL / VOLUME II NOMOR I / TAHUN 2013}

Kualitas pelayanan (service quality) dapat diketahui dengan cara membandingkan persepsi para konsumen atas pelayanan yang nyata-nyata mereka peroleh dengan pelayanan yang sesungguhnya mereka harapkan atau inginkan terhadap atribut-atribut pelayanan suatu perusahaan. Jika jasa yang diterima atau dirasakan (perceived service) sesuai dengan yang diharapkan, maka kualitas pelayanan dipersepsikan baik dan memuaskan, jika jasa yang diterima melampaui harapan konsumen, maka kualitas pelayanan dipersepsikan sangat baik dan berkualitas.

Hipotesis pada penelitian ini yaitu (1) Kemudahan Penggunakan berpengaruh positif dan signifikan terhadap Minat Menggunakan Internet Banking pada nasabah Bank Mandiri, (2) Kepercayaan berpengaruh positif dan signifikan terhadap Minat Menggunakan Internet Banking pada nasabah Bank Mandiri, (3) Kecemasan Berkomputer berpengaruh positif dan signifikan terhadap Minat Menggunakan Internet Banking pada nasabah Bank Mandiri, (4) Kualitas Layanan berpengaruh positif dan signifikan terhadap Minat Menggunakan Internet Banking pada nasabah Bank Mandiri, (5) Kemudahan Penggunaan, Kepercayaan, Kecemasan Berkomputer, dan Kualitas Informasi secara stimultan berpengaruh positif dan signifikan.

\section{METODE PENELITIAN}

Jenis penelitian ini adalah penelitian kuantitatif asosiatif dengan unit analisis yang diteliti adalah nasabah para pengguna layanan internet banking pada Bank Mandiri. Penelitian kuantitatif asosiatif adalah penelitian yang bertujuan untuk mengetahui hubungan dua variabel atau lebih (Sugiyono, 2009). Penelitian asosiatif ini bertujuan untuk mengetahui faktor kemudahan penggunaan $\left(\mathrm{X}_{1}\right)$, kepercayaan $\left(\mathrm{X}_{2}\right)$, kecemasan berkomputer $\left(\mathrm{X}_{3}\right)$ dan kualitas layanan $\left(\mathrm{X}_{4}\right)$ berpengaruh terhadap $\mathrm{Y}$ (minat menggunakan internet banking).

\section{Populasi dan Sampel Penelitian}

Populasi pada penelitian ini adalah nasabah yang merupakan penabung dan menggunakan layanan Internet Banking pada Bank Mandiri. Dengan pertimbangan tentang efisiensi waktu dan tenaga maka digunakanlah sampel untuk mengambil data dari responden. Sampel adalah bagian dari jumlah dan karakteristik yang dimiliki oleh populasi mereka. Dalam hal ini sampel penelitian yang digunakan adalah nasabah Bank Mandiri cabang Jl. Jendral Soedirman Yogyakarta. 


\section{Tempat dan Waktu Penelitian}

Lokasi penelitian dilakukan di Bank Mandiri cabang Jl. Jendral Soedirman Yogyakarta yang dilakukan pada bulan April 2012.

\section{Instrumen Penelitian}

Dengan Skala Likert, maka variabel yang akan diukur dijabarkan menjadi indikator variabel. Kemudian indikator tersebut dijadikan sebagai titik tolak untuk menyusun item-item instrumen yang dapat berupa pernyataan atau pertanyaan. Untuk keperluan analisis kuantitatif, biasanya disediakan lima pilihan skala dengan kriteria sebagai berikut:

Tabel 1. Kriteria Skala Pengukuran

\begin{tabular}{|c|c|c|c|}
\hline No & Jawaban & Kode & Bobot \\
\hline 1 & Sangat Tidak Setuju & STS & 1 \\
\hline 2 & Tidak Setuju & TS & 2 \\
\hline 3 & Ragu-ragu & R & 3 \\
\hline 4 & Setuju & S & 4 \\
\hline 5 & Sangat Setuju & SS & 5 \\
\hline
\end{tabular}

Tabel 2. Kisi-kisi Instrumen Penelitian

\begin{tabular}{|c|c|c|c|}
\hline No & Variabel & Indikator & $\begin{array}{l}\text { Nomor } \\
\text { Item }\end{array}$ \\
\hline 1 & $\begin{array}{l}\text { Minat } \\
\text { Menggunakan }\end{array}$ & $\begin{array}{l}\text { 1. Keinginan untuk menggunakan } \\
\text { teknologi } \\
\text { 2. Dukungan terhadap teknologi } \\
\text { yang digunakan } \\
\text { 3. Perhatian terhadap } \\
\text { perkembangan teknologi }\end{array}$ & $\begin{array}{l}1,2, \\
3,4, \\
5,6,\end{array}$ \\
\hline 2 & $\begin{array}{l}\text { Kemudahan } \\
\text { Penggunaan }\end{array}$ & $\begin{array}{l}\text { 1. Kemudahan } \\
\text { 2. Produktivitas } \\
\text { 3. Efektivitas } \\
\text { 4. Kegunaan }\end{array}$ & $\begin{array}{l}7,8,9, \\
10,11,12, \\
13,14,15, \\
16,17,18,\end{array}$ \\
\hline 3 & Kepercayaan & $\begin{array}{l}\text { 1. Orientasi Teknologi } \\
\text { 2. Reputasi } \\
\text { 3. Risiko }\end{array}$ & $\begin{array}{l}19,20,21, \\
22,23,24, \\
25,26,27\end{array}$ \\
\hline 4 & $\begin{array}{l}\text { Kecemasan } \\
\text { Berkomputer }\end{array}$ & $\begin{array}{l}\text { 1. Dampak } \\
\text { 2. Penilaian }\end{array}$ & $\begin{array}{l}28,29,30, \\
31,32,33,\end{array}$ \\
\hline 5 & $\begin{array}{l}\text { Kualitas } \\
\text { Layanan }\end{array}$ & $\begin{array}{ll}\text { 1. } & \text { Kinerja } \\
\text { 2. } & \text { Fitur } \\
\text { 3. } & \text { Kehandalan } \\
\text { 4. Kesesuaian } \\
\text { 5. } & \text { Estetika } \\
\end{array}$ & $\begin{array}{l}34,35,36, \\
37,38,39, \\
40,41,42, \\
43,44,45, \\
46,47,48\end{array}$ \\
\hline
\end{tabular}




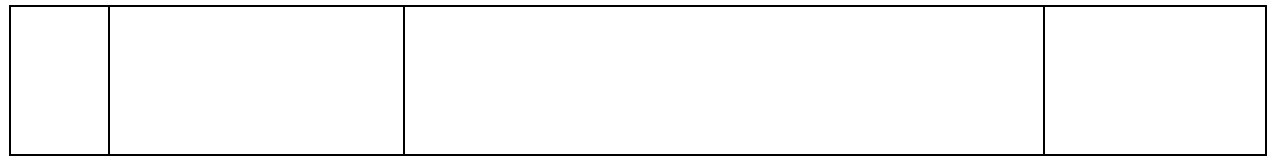

\section{Teknik Pengumpulan Data}

Teknik pengambilan sampel menggunakan teknik purposive sampling, yaitu teknik penentuan sampling dengan pertimbangan tertentu (Sugiyono, 2009). Pertimbangan tertentu dalam penelitian ini adalah responden yang diminta mengisi kuisioner memiliki kriteria sebagai nasabah Bank Mandiri Yogyakarta.

Pengukuran variabel independen atau variabel bebas yang digunakan dalam penelitian ini yaitu persepsi kemudahan penggunaan, kepercayaan, kecemasan berkomputer, kualitas layanan dan variabel dependen yaitu minat menggunakan internet banking yang sama-sama diukur menggunakan instrumen kuesioner. Semua pertanyaan dalam kuesioner tersebut dinilai dengan skala Likert 1-5. (Sugiyono, 2009:93).

\section{Uji Coba Instrumen}

\section{a. Uji Validitas}

Uji signifikasi dilakukan dengan membandingkan nilai $r$ hitung dengan $r$ tabel. Jika $r$ hitung lebih besar dari $r$ tabel dan nilai positif maka butir atau pertanyaan atau indikator tersebut dinyatakan valid, tapi jika sebaliknya, maka dianggap tidak valid (Imam Ghozali, 2006). Dengan bantuan SPSS 17.0 diperoleh rangkuman hasil perhitungan uji validitas seperti tercantum pada tabel 3 .

Tabel 3. Hasil Pengujian Uji Validitas Butir-Butir Pernyataan

\begin{tabular}{|l|c|c|c|}
\hline \multicolumn{1}{|c|}{ Item Pertanyaan } & Jumlah Butir & Jumlah Valid & Jumlah Gugur \\
\hline Kemudahan Penggunaan & 11 & 11 & - \\
\hline Kepercayaan & 9 & 9 & - \\
\hline Kecemasan Berkomputer & 6 & 5 & 1 \\
\hline Kualitas Layanan & 15 & 15 & - \\
\hline Minat Menggunakan & 6 & 6 & - \\
\hline
\end{tabular}

Sumber: data primer yang diolah 
Pada variabel Kecemasan Bekomputer terdapat satu butir pertanyaan yang dinyatakan tidak valid dan tidak dapat digunakan pada penelitian yaitu butir nomor 3 karena nilai correlation bernilai 0,289 dibawah 0,361.

\section{b. Uji Reliabilitas}

Uji reliabilitas adalah suatu instrumen cukup dapat dipercaya untuk digunakan sebagai alat pengumpul data karena instrumen tersebut sudah cukup baik. Uji reliabilitas dilakukan dengan menggunakan koefisien Cronbach Alpha dengan rumus sebagai berikut:

Kriteria pengujian instrumen dikatakan andal apabila $\mathrm{r}$ hitung lebih besar dari $r$ tabel pada taraf signifikansi 5\%. Pada penelitian ini untuk menginterpretasikan hasil uji coba instrumen menggunakan pedoman sebagai berikut:

Tabel 4. Interpretasi Nilai $r$

\begin{tabular}{|l|l|}
\hline Besarnya Nilai $r$ & Interpretasi \\
\hline $0,800-1,000$ & Sangat tinggi \\
\hline $0,600-0,799$ & Tinggi \\
\hline $0,400-0,599$ & Sedang \\
\hline $0,200-0,399$ & Rendah \\
\hline $0,000-0,199$ & Sangat Rendah \\
\hline
\end{tabular}

Dari kelima tingkat keandalan koefisien di atas, yang digunakan sebagai indikator instrumen dikatakan reliabel adalah 0,600. Jadi instrumen dikatakan reliabel jika mempunyai tingkat keandalan koefisien $\geq 0,600$. Perhitungan untuk mencari tingkat keandalan data instrumen dalam penelitian ini dibantu program SPSS 17.0.

Tabel 5. Uji Reliabilitas Variabel

\begin{tabular}{|c|c|c|}
\hline Nama Variabel & Koefisien Alpha & Keterangan \\
\hline Kemudahan Penggunaan & 0,761 & Reliabel \\
\hline Kepercayaan & 0,721 & Reliabel \\
\hline Kecemasan Berkomputer & 0,701 & Reliabel \\
\hline Kualitas Layanan & 0,746 & Reliabel \\
\hline Minat Menggunakan & 0,785 & Reliabel \\
\hline
\end{tabular}

Sumber: data primer yang diolah

Berdasarkan tabel 5, instrumen Kemudahan Penggunaan Teknologi, Keamanan, Kualitas Informasi, dan Minat Menggunakan internet banking 
dapat dikatakan reliabel dan telah memenuhi syarat untuk digunakan dalam penelitian.

\section{Teknik Analisis Data}

\section{a. Analisis Deskriptif}

\section{b. Uji Persyaratan Analisis}

\section{1) Uji Normalitas}

Uji normalitas dapat dilakukam dengan menggunakan uji statistik nonparametrik Kolmogrov-Smirnov (Uji K-S). Uji K-S dilakukan dengan membuat hipotesis.

\section{2) Uji Linieritas}

Uji linieritas untuk mengetahui apakah masing-masing variabel yang dijadikan prediktor mempunyai hubungan linier atau tidak dengan variabel dependen.

\section{3) Uji Multikolinieritas}

Uji multikolinieritas bertujuan untuk menguji apakah model regresi ditemukan adanya korelasi antar variabel bebas (independen).

\section{4) Uji Heteroskedastisitas}

Uji heteroskedastisitas bertujuan menguji apakah dalam model regresi terjadi ketidaksamaan varian dari residual satu pengamatan ke pengamatan yang lain (Imam Ghozali, 2011:119).

\section{c. Uji Hipotesis}

\section{1) Analisi Regresi Sederhana}

Analisis ini digunakan untuk mengetahui bagaimana pengaruh variabel independen $\left(\mathrm{X}_{1}\right),\left(\mathrm{X}_{2}\right)$, dan $\left(\mathrm{X}_{3}\right)$ terhadap variabel dependen $(\mathrm{Y})$.

\section{2) Analisis Regresi Berganda}

Regresi berganda (multiple regression) adalah suatu perluasan dari teknik regresi apabila terdapat lebih dari satu variabel bebas untuk mengadakan prediksi terhadap variabel terikat (Suharsimi, 2006:295). 


\section{HASIL PENELITIAN DAN PEMBAHASAN}

\section{Data Responden Penelitian}

\section{a. Data Responden Penelitian Berdasarkan Jenis Kelamin}

Deskripsi data responden berdasarkan jenis kelamin dapat dilihat pada tabel berikut:

Tabel 4. Demografi Responden Berdasarkan Jenis Kelamin

\begin{tabular}{|l|c|c|}
\hline \multicolumn{1}{|c|}{ Jenis Kelamin } & Frekuensi & Presentase \\
\hline Laki-laki & 67 & $48,20 \%$ \\
\hline Perempuan & 72 & $51,80 \%$ \\
\hline Jumlah & 139 & $100 \%$ \\
\hline
\end{tabular}

Sumber: data primer yang diolah

Data tersebut menunjukkan jumlah persentase responden laki-laki yang mengakses internet banking sejumlah 67 orang $(48,20 \%)$, sedangkan responden perempuan yang mengakses internet banking sejumlah 72 orang $(51,80 \%)$.

b. Deskripsi Responden Umur

Deskripsi data responden berdasarkan umur dapat dilihat pada tabel berikut:

Tabel 5. Demografi Responden Berdasarkan Umur

\begin{tabular}{|c|c|c|}
\hline Umur & Frekuensi & Persentase \\
\hline 19 tahun & 11 & $7,9 \%$ \\
\hline 20 tahun & 27 & $19,4 \%$ \\
\hline 21 tahun & 18 & $12,9 \%$ \\
\hline 22 tahun & 15 & $10,8 \%$ \\
\hline 23 tahun & 8 & $5,8 \%$ \\
\hline 24 tahun & 14 & $10,1 \%$ \\
\hline 25 tahun & 5 & $3,6 \%$ \\
\hline 26 tahun & 10 & $7,2 \%$ \\
\hline 27 tahun & 27 & $19,4 \%$ \\
\hline 28 tahun & 3 & $2,2 \%$ \\
\hline 30 tahun & 1 & $0,7 \%$ \\
\hline Jumlah & 139 & $100 \%$ \\
\hline
\end{tabular}

Sumber: data primer yang diolah 
Dari data diatas dapat ditentukan jumlah persen nasabah yang menggunakan internet banking dengan frekuensi datanya.

\section{Deskripsi Variabel Penelitian}

Analisis deskriptif pada penelitian ini meliputi mean, median, modus, tabel frekuensi responden, dan tabel frekuensi responden menurut kategori yang penentuannya menggunakan bantuan program SPSS 17.0.. Deskripsi data dari masing-masing variabel secara rinci dapat dilihat dalam uraian berikut ini:

\section{a. Minat Menggunakan Internet Banking}

Kuisioner variabel Minat Menggunakan Internet Banking terdiri dari 6 item pertanyaan. Nilai tertinggi adalah 27 , nilai terendah 9 , mean 18 , dan standar deviasi ideal 3. Pada penelitian digunakan 2 kali standar deviasi untuk menilai tingkat sebaran data.

$$
\begin{gathered}
\text { Mean }+2 \text { standar deviasi }=18+2(3) \\
=24
\end{gathered}
$$

Hasil perhitungan dua kali standar deviasi sebesar 24 mendekati nilai 27, sehingga dapat dikatakan baik.

Jumlah kelas interval setelah dihitung dengan rumus Sturges sebanyak 8 kelas. Jawaban responden pada variabel Minat Menggunakan Internet Banking dapat dilihat pada tabel 9 sebagai berikut:

Tabel 6. Distribusi Frekuensi Variabel Minat Menggunakan Internet Banking

\begin{tabular}{|c|c|c|}
\hline No & Interval & Frekuensi \\
\hline 1. & $9-11$ & 6 \\
\hline 2 & $12-14$ & 36 \\
\hline 3 & $15-17$ & 34 \\
\hline 4 & $18-20$ & 26 \\
\hline 5 & $21-23$ & 28 \\
\hline 6 & $24-26$ & 8 \\
\hline 7 & $27-29$ & 1 \\
\hline 8 & $30-32$ & 0 \\
\hline \multicolumn{2}{|c|}{ Jumlah } & 139 \\
\hline
\end{tabular}


Sumber: data primer yang diolah

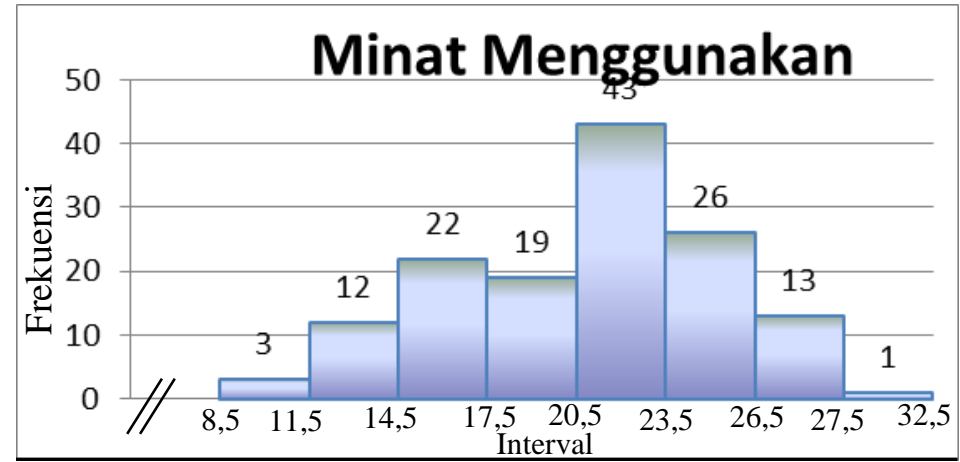

Gambar 1. Histogram Variabel Minat Menggunakan Internet Banking

Tabel 6 menunjukkan bahwa frekuensi yang paling besar adalah 36 pada interval antara 12-14 dengan presentase sebesar 25,9\% sedangkan frekuensi paling rendah adalah 0 pada interval antara 30-32 dengan presentase sebesar 0\%.

Tabel 7. Distribusi Kecenderungan Data Variabel Minat Menggunakan Internet Baking

\begin{tabular}{|l|l|c|c|c|}
\hline No & Kategori & Inteval & Frekuensi & Frekuensi Relatif \\
\hline 1. & Tinggi & $>21$ & 28 & $20,1 \%$ \\
\hline 2. & Sedang & $>15$ s/d 21 & 54 & $38,9 \%$ \\
\hline 3. & Rendah & $<15$ & 57 & $41,0 \%$ \\
\hline \multicolumn{3}{|c|}{ Jumlah } & 139 & $100 \%$ \\
\hline
\end{tabular}

Sumber: data primer yang diolah

Tabel 7 menujukkan bahwa kategori tinggi sebanyak 28 responden (20,1\%), kategori sedang sebanyak 54 responden (38,9\%), dan kategori rendah sebanyak 57 responden $(41,0 \%)$.

\section{b. Kemudahan Penggunaan}

Kuisoner variabel Kemudahan Penggunaan terdiri dari 11 item pertanyaan. Nilai tertinggi adalah 49, nilai terendah 16 , mean 32,5 , dan standar deviasi ideal 5,5. Pada penelitian digunakan 2 kali standar deviasi untuk menilai tingkat sebaran data.

$$
\begin{gathered}
\text { Mean + } 2 \text { standar deviasi }=32,5+2(5,5) \\
=43,5
\end{gathered}
$$


Hasil perhitungan dua kali standar deviasi sebesar 43,5 mendekati nilai 49, sehingga dapat dikatakan baik.

Jumlah kelas interval setelah dihitung dengan rumus Sturges sebanyak 8 kelas. Jawaban responden pada variabel Kemudahan Penggunaan dapat dilihat pada tabel 8 sebagai berikut:

Tabel 8. Distribusi Frekuensi Variabel Kemudahan Penggunaan

\begin{tabular}{|c|c|c|}
\hline No & Interval & Frekuensi \\
\hline 1. & $16-20$ & 2 \\
\hline 2 & $21-25$ & 34 \\
\hline 3 & $26-30$ & 11 \\
\hline 4 & $31-35$ & 13 \\
\hline 5 & $36-40$ & 47 \\
\hline 6 & $41-45$ & 22 \\
\hline 7 & $46-50$ & 10 \\
\hline 8 & $41-55$ & 0 \\
\hline \multicolumn{2}{|c|}{ Jumlah } & 139 \\
\hline
\end{tabular}

Sumber : data primer yang diolah

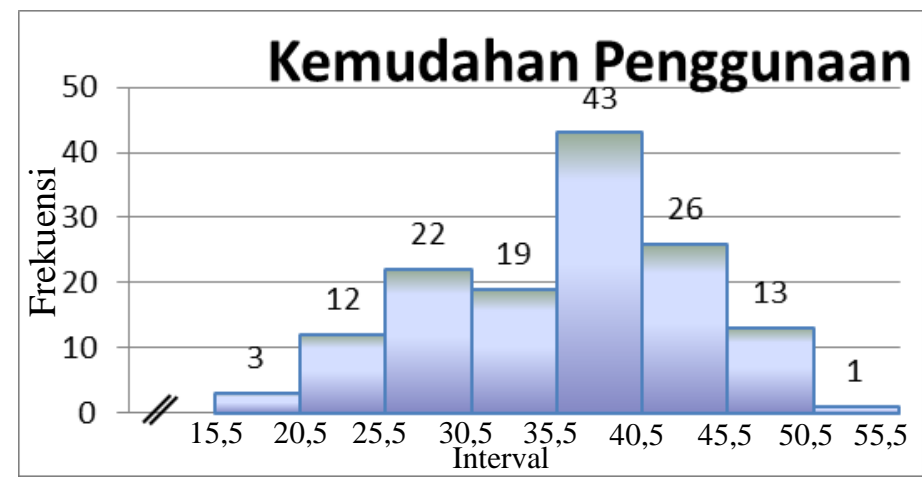

Gambar 2. Histogram Variabel Kemudahan Penggunaan

Tabel 8 menunjukkan bahwa frekuensi yang paling besar adalah 47 pada interval antara 36-40 dengan presentase sebesar 33,8\% sedangkan frekuensi paling rendah adalah 0 pada interval antara 41-55 dengan presentase sebesar $0 \%$.

Berikut tabel 9 mengenai distribusi kecenderungan data variabel Kemudahan Penggunaan.

Tabel 9. Distribusi Kecenderungan Data Variabel Kemudahan Penggunaan

\begin{tabular}{|l|l|c|c|c|}
\hline No & Kategori & Inteval & Frekuensi & Frekuensi Relatif \\
\hline 1. & Tinggi & $>38$ & 59 & $42,4 \%$ \\
\hline 2. & Sedang & $>27$ s/d 38 & 35 & $25,2 \%$ \\
\hline 3. & Rendah & $<27$ & 45 & $32,4 \%$ \\
\hline \multicolumn{3}{|c|}{ Jumlah } & 139 & $100 \%$ \\
\hline
\end{tabular}


Sumber: data primer yang diolah

Tabel 9 menujukkan bahwa kategori tinggi sebanyak 59 responden $(42,4 \%)$, katergori sedang sebanyak 35 responden $(25,2 \%)$, dan kategori rendah sebanyak 45 responden $(32,4 \%)$.

\section{c. Kepercayaan}

Kuisioner variabel Kepercayaan terdiri dari 9 pertanyaan. Nilai tertinggi adalah 39, nilai terendah 13, mean 26, standar deviasi ideal 4,3. Pada penelitian digunakan 2 kali standar deviasi untuk menilai tingkat sebaran data.

$$
\begin{aligned}
\text { Mean }+2 \text { standar deviasi } & =26+2(4,3) \\
& =34,5
\end{aligned}
$$

Hasil perhitungan dua kali standardeviasi sebesar 34,5 mendekati nilai 39, sehingga dapat dikatakan baik.

Jumlah kelas interval setelah dihitung dengan rumus Sturges sebanyak 8 kelas. Jawaban responden pada variabel Kepercayaan dapat dilihat pada tabel 10 sebagai berikut:

Tabel 10. Distribusi Frekuensi Variabel Kepercayaan

\begin{tabular}{|c|c|c|}
\hline No & Interval & Frekuensi \\
\hline 1. & $13-16$ & 6 \\
\hline 2 & $17-20$ & 14 \\
\hline 3 & $21-24$ & 29 \\
\hline 4 & $25-28$ & 22 \\
\hline 5 & $29-32$ & 39 \\
\hline 6 & $33-36$ & 23 \\
\hline 7 & $37-40$ & 6 \\
\hline 8 & $41-44$ & 0 \\
\hline \multicolumn{2}{|c|}{ Jumlah } & 139 \\
\hline
\end{tabular}

Sumber : data primer yang diolah

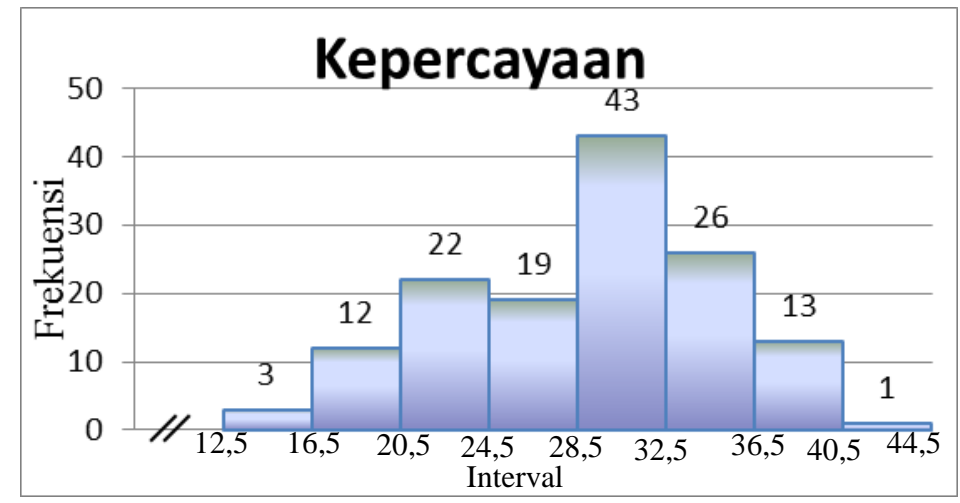

Gambar 3. Histogram Variabel Kepercayaan 
Tabel 10 menunjukkan bahwa frekuensi yang paling besar adalah 39 pada interval antara 29-32 dengan presentase sebesar 28,1\% sedangkan frekuensi paling rendah adalah 0 pada interval antara 41-44 dengan presentase sebesar $0 \%$.

Berikut tabel 11 mengenai distribusi kecenderungan data variabel Kepercayaan.

Tabel 11. Distribusi Kecenderungan Data Variabel Kepercayaan

\begin{tabular}{|l|l|c|c|c|}
\hline No & Kategori & Inteval & Frekuensi & Frekuensi Relatif \\
\hline 1. & Tinggi & $>30,3$ & 50 & $36,0 \%$ \\
\hline 2. & Sedang & $\begin{array}{c}>21,7 \mathrm{~s} / \mathrm{d} \\
30,3\end{array}$ & 60 & $43,1 \%$ \\
\hline 3. & Rendah & $<21,7$ & 29 & $20,9 \%$ \\
\hline \multicolumn{3}{|c|}{ Jumlah } & 139 & $100 \%$ \\
\hline
\end{tabular}

Sumber: data primer yang diolah

Tabel 11 menujukkan bahwa kategori tinggi sebanyak 50 responden (36\%), katergori sedang sebanyak 60 responden $(43,1 \%)$, dan kategori rendah sebanyak 29 responden $(20,9 \%)$.

\section{d. Kecemasan Berkomputer}

Kuisioner variabel Minat Menggunakan Internet Banking terdiri dari 5 item pertanyaan. Nilai tertinggi adalah 22, nilai terendah 5, mean 13,5, dan standar deviasi ideal 8,5. Pada penelitian digunakan 2 kali standar deviasi untuk menilai tingkat sebaran data.

$$
\begin{aligned}
\text { Mean }+2 \text { standar deviasi } & =13,5+2(8,5) \\
& =30,5
\end{aligned}
$$

Hasil perhitungan dua kali standar deviasi sebesar 30,5 mendekati nilai 22, sehingga dapat dikatakan baik.

Jumlah kelas interval setelah dihitung dengan rumus Sturges sebanyak 8 kelas. Jawaban responden pada variabel Minat Menggunakan Internet Banking dapat dilihat pada tabel 12 sebagai berikut: 
Tabel 12. Distribusi Frekuensi Variabel Kecemasan berkomputer

\begin{tabular}{|c|c|c|}
\hline No & Interval & Frekuensi \\
\hline 1. & $5-7$ & 3 \\
\hline 2 & $8-10$ & 12 \\
\hline 3 & $11-13$ & 20 \\
\hline 4 & $14-16$ & 27 \\
\hline 5 & $17-19$ & 40 \\
\hline 6 & $20-22$ & 37 \\
\hline 7 & $23-25$ & 0 \\
\hline 8 & $26-28$ & 0 \\
\hline \multicolumn{2}{|c|}{ Jumlah } & 139 \\
\hline
\end{tabular}

Sumber : data primer yang diolah

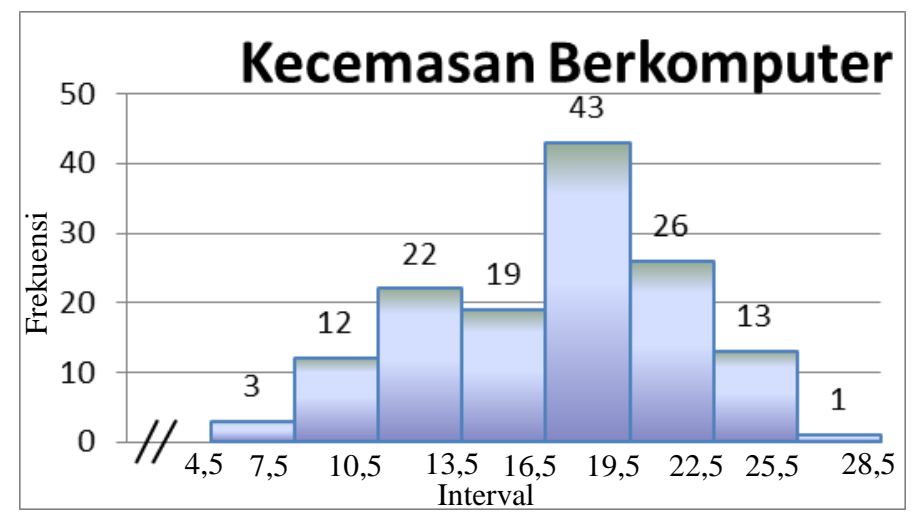

Gambar 4. Histogram Variabel Kecemasan Berkomputer

Tabel 12 menunjukkan bahwa frekuensi yang paling besar adalah 40 pada interval antara 17-19 dengan presentase sebesar 28,8\% sedangkan frekuensi paling rendah adalah 0 pada interval antara 26-28 dengan presentase sebesar $0 \%$.

Berikut tabel 13 mengenai distribusi kecenderungan data variabel Kecemasan Berkomputer.

Tabel 13. Distribusi Kecenderungan data Variabel Kecemasan Berkomputer

\begin{tabular}{|l|l|c|c|c|}
\hline No & Kategori & Inteval & Frekuensi & Frekuensi Relatif \\
\hline 1. & Tinggi & $>22$ & 2 & $1,4 \%$ \\
\hline 2. & Sedang & $>5$ s/d 22 & 135 & $97,2 \%$ \\
\hline 3. & Rendah & $<5$ & 2 & $1,4 \%$ \\
\hline \multicolumn{3}{|c|}{ Jumlah } & 139 & $100 \%$ \\
\hline
\end{tabular}

Sumber : data primer yang diolah

Tabel 13 menujukkan bahwa kategori tinggi sebanyak 2 responden $(1,4 \%)$, katergori sedang sebanyak 135 responden (97,2\%), dan kategori rendah sebanyak 2 responden $(1,4 \%)$. 


\section{e. Kualitas Layanan}

Kuisioner variabel Kualitas Layanan terdiri dari 15 item pertanyaan. Nilai tertinggi adalah 67, nilai terendah 24, mean 45,5, dan standar deviasi ideal 6,7. Pada penelitian digunakan 2 kali standar deviasi untuk menilai tingkat sebaran data.

$$
\begin{gathered}
\text { Mean + } 2 \text { standar deviasi }=45,5+2(6,7) \\
=58,9
\end{gathered}
$$

Hasil perhitungan dua kali standar deviasi sebesar 58,9 mendekati nilai 67, sehingga dapat dikatakan baik.

Jumlah kelas interval setelah dihitung dengan rumus Sturges sebanyak 8 kelas. Jawaban responden pada variabel Kualitas Layanan dapat dilihat pada tabel 14 sebagai berikut:

Tabel 14. Distribusi Frekuensi Variabel Kualitas Layanan

\begin{tabular}{|c|c|c|}
\hline No & Interval & Frekuensi \\
\hline 1. & $24-29$ & 3 \\
\hline 2 & $30-35$ & 12 \\
\hline 3 & $36-41$ & 22 \\
\hline 4 & $42-47$ & 19 \\
\hline 5 & $48-53$ & 43 \\
\hline 6 & $54-59$ & 26 \\
\hline 7 & $60-65$ & 13 \\
\hline 8 & $66-71$ & 1 \\
\hline \multicolumn{2}{|c|}{ Jumlah } & 139 \\
\hline
\end{tabular}

Sumber : data primer yang diolah

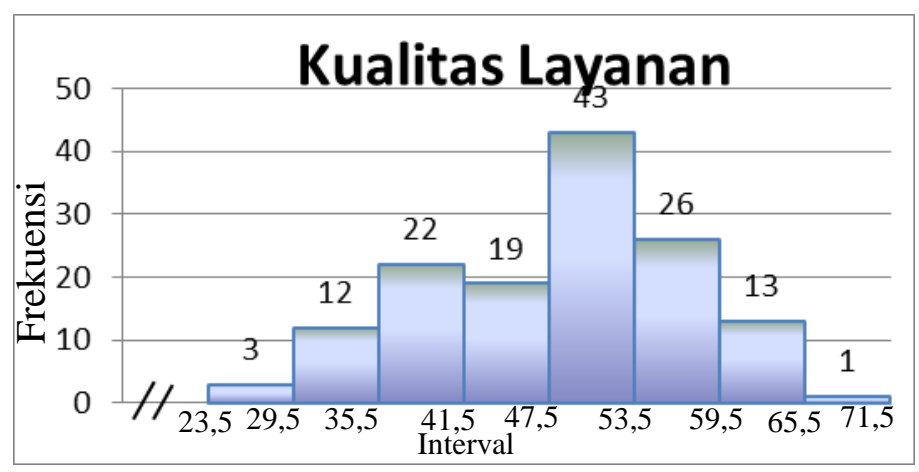

Gambar 5. Histogram Variabel Kualitas Layanan

Tabel 14 menunjukkan bahwa frekuensi yang paling besar adalah 43 pada interval antara 48-53 dengan presentase sebesar 30,9\% sedangkan frekuensi 
paling rendah adalah 1 pada interval antara 66-71 dengan presentase sebesar $0,7 \%$.

Berikut tabel 15 mengenai distribusi kecenderungan data variabel Kualitas Layanan.

Tabel 15. Distribusi Kecenderungan Data Variabel Kualitas Layanan

\begin{tabular}{|c|c|c|c|c|}
\hline No & Kategori & Inteval & Frekuensi & Frekuensi Relatif \\
\hline 1. & Tinggi & $>52,2$ & 45 & $32,4 \%$ \\
\hline 2. & Sedang & $>38,8 \mathrm{~s} / \mathrm{d} 52,2$ & 69 & $49,6 \%$ \\
\hline 3. & Rendah & $<38,8$ & 25 & $18 \%$ \\
\hline \multicolumn{3}{|c|}{ Jumlah } & 139 & $100 \%$ \\
\hline
\end{tabular}

Sumber : data primer yang diolah

Tabel 15 menujukkan bahwa kategori tinggi sebanyak 45 responden (32,4\%), katergori sedang sebanyak 69 responden (49,6\%), dan kategori rendah sebanyak 25 responden $(18 \%)$.

\section{Uji Prasyarat Analisis}

\section{a. Uji Normalitas}

Hasil perhitungan uji normalitas dapat dilihat pada tabel 19 sebagai berikut:

Tabel 16. Hasil Uji Normalitas

\begin{tabular}{|c|c|}
\hline Keterangan & Unstandardized Residual \\
\hline Asymp. Sig. (2-tailed) & 0,251 \\
\hline
\end{tabular}

Berdasarkan hasil uji normalitas di atas, nilai Asymp. Sig. diatas 0,05 maka dapat disimpulkan bahwa data distribusi normal.

\section{b. Uji Linearitas}

Hasil perhitungan uji linearitas dapat dilihat pada tabel 20 sebagai berikut:

Tabel 17. Hasil Uji Linieritas

\begin{tabular}{|c|c|c|}
\hline Hubungan & $\begin{array}{c}\text { Deviation From } \\
\text { Linearity }\end{array}$ & Kriteria \\
\hline $\mathrm{X} 1-\mathrm{Y}$ & 0,629 & Liniear \\
\hline $\mathrm{X} 2-\mathrm{Y}$ & 0,730 & Liniear \\
\hline $\mathrm{X} 3-\mathrm{Y}$ & 0,570 & Liniear \\
\hline $\mathrm{X} 4-\mathrm{Y}$ & 0,463 & Liniear \\
\hline
\end{tabular}

Sumber: data primer yang diolah 
Berdasarkan hasil linearitas di atas menunjukkan bahwa Deviation From Linearity untuk keempat hubungan tersebut memiliki nilai signifikansi di atas 0,05. Sehingga dapat disimpulkan bahwa hubungan tersebut linear dan dapat digunakan untuk menguji regresi linear.

\section{c. Uji Multikolinearitas}

Hasil perhitungan uji multikolinearitas dapat dilihat pada tabel 18 sebagai berikut:

Tabel 18. Hasil Uji Multikolinearitas

\begin{tabular}{|c|c|c|}
\hline Variabel & Tolerance & VIF \\
\hline $\mathrm{X} 1$ & 0,381 & 2.624 \\
\hline $\mathrm{X} 2$ & 0,372 & 2.685 \\
\hline $\mathrm{X} 3$ & 0,345 & 2.900 \\
\hline $\mathrm{X} 4$ & 0,460 & 2.173 \\
\hline
\end{tabular}

Sumber: data primer yang diolah

Berdasarkan hasil uji multikolinearitas di atas, nilai Tolerance $>0,1$ dan VIF $<10$ dapat disimpulkan bahwa tidak ada multikolinearitas dalam model regresi.

\section{d. Uji Heteroskedastisitas}

Hasil uji heteroskedastisitas dapat dilihat pada tabel 19 sebagai berikut:

Tabel 19. Hasil Uji Heteroskedastisitas

\begin{tabular}{|c|c|}
\hline Variabel & Sig. \\
\hline $\mathrm{X} 1$ & 0,204 \\
\hline $\mathrm{X} 2$ & 0,676 \\
\hline $\mathrm{X} 3$ & 0,726 \\
\hline $\mathrm{X} 4$ & 0,878 \\
\hline
\end{tabular}

Sumber : data primer yang diolah

Terlihat dari probabilitas signifikansinya di atas 0,05. Jadi dapat disimpulkan bahwa model regresi tidak mengandung adanya heteroskedastisitas. 


\section{Uji Hipotesis}

\section{a. Analisis Regresi Sederhana}

1) Pengaruh Kemudahan Penggunaan $\left(X_{1}\right)$ terhadap Minat Menggunakan Internet Banking $(Y)$

Berdasarkan output perhitungan regresi sederhana dengan program SPSS 17.0 diperoleh hasil seperti yang disajikan pada tabel 20 berikut:

Tabel 20. Tabel Regresi $X_{1}$ Terhadap $Y$

\begin{tabular}{|c|c|}
\hline Keterangan & Hasil \\
\hline $\mathrm{r}$ & 0,715 \\
\hline$r^{2}$ & 0,512 \\
\hline B Constant & 5,216 \\
\hline B X1 & 0,352 \\
\hline $\mathrm{t}$ & 11.986 \\
\hline Sig. & 0,000 \\
\hline
\end{tabular}

Dari tabel 20 dapat diperoleh persamaan regresi sebagai berikut:

$$
Y=5,216+0,352 X_{1}
$$

Hasil analisis regresi sederhana dengan satu prediktor menunjukkan nilai $r_{\text {hitung }}$ positif sebesar 0,715 yang berarti bahwa terdapat pengaruh positif antara Kemudahan Penggunaan terhadap Minat Menggunakan Internet Banking.

Koefisien determinasi $\left(r^{2}\right)$ sebesar 0,512 menunjukkan bahwa sebesar 51,2\% variabel Minat Menggunakan Internet Banking dipengaruhi oleh variabel Kemudahan Penggunaan, dan sisanya sebesar 48,8\% dipengaruhi oleh variabel lain yang tidak diteliti pada penelitian ini.

Nilai t hitung sebesar 11,986 (di atas nilai t tabel 1,960 pada lampiran halaman 159) mengindikasikan bahwa variabel Kemudahan Penggunaan berpengaruh secara signifikan terhadap variabel Minat Menggunakan Internet Banking. 


\section{2) Pengaruh Kepercayaan $\left(X_{2}\right)$ terhadap Minat Menggunakan Internet} Banking $(Y)$

Berdasarkan output perhitungan regresi sederhana dengan program SPSS 17.0 diperoleh hasil seperti yang disajikan pada tabel 21 berikut:

Tabel 21. Tabel Regresi $X_{2}$ Terhadap $Y$

\begin{tabular}{|c|c|}
\hline Keterangan & Hasil \\
\hline $\mathrm{r}$ & 0,578 \\
\hline$r^{2}$ & 0,334 \\
\hline B Constant & 6,876 \\
\hline $\mathrm{B} \mathrm{X} 1$ & 0,385 \\
\hline $\mathrm{t}$ & 8,282 \\
\hline Sig. & 0,000 \\
\hline
\end{tabular}

Dari tabel 21 dapat diperoleh persamaan regresi sebagai berikut:

$$
Y=6,876+0,385 X_{2}
$$

Hasil analisis regresi sederhana dengan satu prediktor menunjukkan nilai $r_{\text {hitung }}$ positif sebesar 0,578 yang berarti bahwa terdapat pengaruh positif antara Kepercayaan terhadap Minat Menggunakan Internet Banking.

Koefisien determinasi $\left(r^{2}\right)$ sebesar 0,334 menunjukkan bahwa sebesar 33,4\% variabel Minat Menggunakan Internet Banking dipengaruhi oleh variabel Kepercayaan, dan sisanya sebesar 66,6\% dipengaruhi oleh variabel lain yang tidak diteliti pada penelitian ini.

Nilai t hitung sebesar 8,282 (di atas nilai t tabel 1,960 pada lampiran halaman 159) mengindikasikan bahwa variabel Kepercayaan berpengaruh secara signifikan terhadap variabel Minat Menggunakan Internet Banking.

\section{3) Pengaruh Kecemasan Berkomputer $\left(X_{3}\right)$ terhadap Minat Menggunakan} Internet Banking $(Y)$

Berdasarkan output perhitungan regresi sederhana dengan program SPSS 17.0 diperoleh hasil seperti yang disajikan pada tabel 22 berikut : 
Tabel 22. Tabel Regresi $X_{3}$ Terhadap $Y$

\begin{tabular}{|c|c|}
\hline Keterangan & Hasil \\
\hline $\mathrm{r}$ & 0,581 \\
\hline$r^{2}$ & 0,337 \\
\hline B Constant & 7,378 \\
\hline B X1 & 0,615 \\
\hline $\mathrm{t}$ & 8,353 \\
\hline Sig. & 0,000 \\
\hline
\end{tabular}

Dari tabel 22 dapat diperoleh persamaan regresi sebagai berikut :

Hasil analisis regresi sederhana dengan satu prediktor menunjukkan nilai $r_{\text {hitung }}$ positif sebesar 0,581 yang berarti bahwa terdapat pengaruh positif antara Kecemasan Berkomputer terhadap Minat Menggunakan Internet Banking. Koefisien determinasi $\left(r^{2}\right)$ sebesar 0,337 menunjukkan bahwa sebesar 33,7\% variabel Minat Menggunakan Internet Banking dipengaruhi oleh variabel Kecemasan Berkomputer, dan sisanya sebesar 66,3\% dipengaruhi oleh variabel lain yang tidak diteliti pada penelitian ini.

Nilai t hitung sebesar 8,353 (di atas nilai t tabel 1,960 pada lampiran halaman 159) mengindikasikan bahwa variabel Kecemasan Berkomputer berpengaruh secara signifikan terhadap variabel Minat Menggunakan Internet Banking.

4) Pengaruh Kualitas Layanan $\left(X_{4}\right)$ terhadap Minat Menggunakan Internet Banking $(Y)$

Berdasarkan output perhitungan regresi sederhana dengan program SPSS 17.0 diperoleh hasil seperti yang disajikan pada tabel 23 berikut :

Tabel 23. Tabel Regresi $X_{4}$ Terhadap $Y$

\begin{tabular}{|c|c|}
\hline Keterangan & Hasil \\
\hline $\mathrm{r}$ & 0,587 \\
\hline$r^{2}$ & 0,345 \\
\hline B Constant & 4,475 \\
\hline B X1 & 0,268 \\
\hline $\mathrm{t}$ & 8,489 \\
\hline Sig. & 0,000 \\
\hline
\end{tabular}


Dari tabel 23 dapat diperoleh persamaan regresi sebagai berikut :

$$
Y=4,475+0,268 X_{4}
$$

Hasil analisis regresi sederhana dengan satu prediktor menunjukkan nilai $r_{\text {hitung }}$ positif sebesar 0,587 yang berarti bahwa terdapat pengaruh positif antara Kualitas Layanan terhadap Minat Menggunakan Internet Banking. Koefisien determinasi $\left(r^{2}\right)$ sebesar 0,345 menunjukkan bahwa sebesar 34,5\% variabel Minat Menggunakan Internet Banking dipengaruhi oleh variabel Kualitas Layanan, dan sisanya sebesar $65,5 \%$ dipengaruhi oleh variabel lain yang tidak diteliti pada penelitian ini

Nilai t hitung sebesar 8,489 (di atas nilai t tabel 1,960 pada lampiran halaman 159) mengindikasikan bahwa variabel Kualitas Layanan berpengaruh secara signifikan terhadap variabel Minat Menggunakan Internet Banking.

\section{b. Analisis Regresi Berganda}

Pengolahan data menggunakan program SPSS 17.0, maka diperoleh hasil seperti yang disajikan pada tabel 24 berikut :

Tabel 24. Tabel Regresi $X_{1}, X_{2}, X_{3}$, dan $X_{4}$ Terhadap $Y$

\begin{tabular}{|c|c|}
\hline Keterangan & Hasil \\
\hline $\mathrm{r}$ & 0,740 \\
\hline$r^{2}$ & 0,548 \\
\hline F hitung & 40,566 \\
\hline B Constant & 2,448 \\
\hline B X1 & 0,274 \\
\hline B X2 & 0,043 \\
\hline B X3 & $-0,023$ \\
\hline B X4 & 0,097 \\
\hline
\end{tabular}

Dari tabel 27 dapat diperoleh persamaan regresi sebagai berikut :

$$
Y=2,448+0,274 X_{1}+0,043 X_{2}-0,023 X_{3}+0,185 X_{4}
$$

Hal ini menandakan regresi berganda tersebut tidak seluruhnya memiliki hubungan yang searah, artinya Minat Menggunakan Internet Banking $(Y)$ akan mengikat seiring dengan meningkatnya Kemudahan Menggunakan $\left(X_{1}\right)$, Kepercayaan $\left(X_{2}\right)$, dan Kualitas Informasi $\left(X_{4}\right)$. Jadi, Kemudahan Penggunaan 
$\left(X_{1}\right)$, Kepercayaan $\left(X_{2}\right)$, dan Kualitas Pelayanan $\left(X_{4}\right)$ berpengaruh positif dan signifikan terhadap Minat Menggunakan $(Y)$. Tetapi tidak untuk variabel Kecemasan Berkomputer $\left(X_{3}\right)$ yang memiliki hubungan negatif terhadap variabel Minat Menggunakan $(Y)$.

Berdasarkan hasil data pada tabel 26, R 0,548. Nilai tersebut berarti 54,8\% perubahan pada variabel Minat Menggunakan Internet Banking $(Y)$ dapat diterangkan oleh variabel-variabel independennya yaitu Kemudahan Penggunaan $\left(X_{1}\right)$, Kepercayaan $\left(X_{2}\right)$, Kecemasan Berkomputer $\left(X_{3}\right)$ dan Kualitas Layanan $\left(X_{4}\right)$, sedangkan sisanya $45,2 \%$ dijelaskan oleh veriabel lain yang tidak diteliti pada penelitian ini.

Berdasarkan hasil uji diperoleh nilai $\mathrm{F}$ hitung sebesar 40,566 (> F tabel 2,670 pada lampiran halaman 160) pada taraf signifikansi 0,05. Nilai F hitung $>$ F tabel dapat dinyatakan bahwa Kemudahan Penggunaan $\left(X_{1}\right)$, Kepercayaan $\left(X_{2}\right)$, Kecemasan Berkomputer $\left(X_{3}\right)$ dan Kualitas Layanan $\left(X_{4}\right)$ secara bersama-sama berpengaruh signifikan terhadap Minat Menggunakan Internet Bangking $(Y)$.

\section{1) Sumbangan Relatif dan Sumbangan Efektif}

Besarnya sumbangan relatif dan sumbangan efektif dapat dilihat pada tabel 24 sebagai berikut:

Tabel 24. Sumbangan Relatif dan Sumbangan Efektif

\begin{tabular}{|c|l|c|c|}
\hline No & \multicolumn{1}{|c|}{ Variabel } & $\begin{array}{c}\text { Sumbangan } \\
\text { Relatif }\end{array}$ & $\begin{array}{c}\text { Sumbangan } \\
\text { Efektif }\end{array}$ \\
\hline 1 & Kemudahan Penggunaan $\left(X_{1}\right)$ & $60,35 \%$ & $33,07 \%$ \\
\hline 2 & Kepercayaan $\left(X_{2}\right)$ & $7,86 \%$ & $4,30 \%$ \\
\hline 3 & Kecemasan Berkomputer $\left(X_{3}\right)$ & $2,5 \%$ & $1,37 \%$ \\
\hline 4 & Kualitas Layanan $\left(X_{4}\right)$ & $29,29 \%$ & $16,05 \%$ \\
\hline \multicolumn{2}{c}{ Jumlah } & $100 \%$ & $54,79 \%$ \\
\hline
\end{tabular}

Sumber: data primer yang diolah

Berdasarkan tabel 24 di atas, dapat diketahui seberapa besar sumbangan relatif dan sumbangan efektif dari masing-masing variabel. 


\section{E. PENUTUP}

\section{Kesimpulan}

Berdasarkan data yang diperoleh dari hasil analisis yang dilakukan maka dapat ditarik kesimpulan sebagai berikut:

a. Terdapat pengaruh positif dan signifikan pada Presepsi Kemudahan Penggunaan terhadap Minat Menggunakan Internet Banking pada nasabah Bank Mandiri Yogyakarta

b. Terdapat pengaruh positif dan signifikan pada Kepercayaan terhadap Minat Menggunakan Internet Banking pada nasabah Bank Mandiri Yogyakarta.

c. Terdapat pengaruh positif dan signifikan pada Kecemasan Berkomputer terhadap Minat Menggunakan Internet Banking pada nasabah Bank Mandiri Yogyakarta.

d. Terdapat pengaruh positif dan signifikan pada Kualitas Layanan terhadap Minat Menggunakan Internet Banking pada nasabah Bank Mandiri Yogyakarta.

e. Terdapat pengaruh positif dan signifikan pada Kemudahan Penggunaan, Kepercayaan, Kualitas Layanan terhadap Minat Menggunakan Internet Banking pada nasabah Bank Mandiri Yogyakarta. Tetapi terdapat pengaruh negatif pada Kecemasan Berkomputer yang menunjukkan jika terjadi kenaikan pada Kecemasan Berkomputer maka terjadi penurunan terhadap Minat Menggunakan Internet Banking pada nasabah Banki Mandiri Yogyakarta.

\section{Implikasi}

a. Persepsi Kemudahan Penggunaan merupakan sistem yang dapat digunakan dan dioperasikan dengan mudah oleh seseorang. Hasil penelitian ini menunjukkan bahwa Kemudahan Penggunaan berpengaruh kepada Minat Menggunakan Internet Banking. Hal ini mengandung implikasi agar kedepannya internet banking melakukan pengembangan dan pemeliharaan kemudahan teknologi yang lebih baik lagi sehingga konsumen lebih mudah bertransaksi.

b. Kepercayaan sangat dibutuhkan pihak bank maupun konsumen agar terjalin ikatan antara keduanya. Keamanan data nasabah perlu dijaga agar tidak terjadi kecurangan atau penipuan. Hal ini mengandung implikasi bahwa internet banking akan 
mencegah atau mengurangi rasa keraguan yang terdapat pada konsumen tentang internet banking.

c. Kecemasan Berkomputer didalam diri nasabah dapat membuat mereka akan menjauhi sistem-sistem yang dijalankan dengan otomatis sehingga data-data dan hasilnya tidak sesuai dengan yang mereka harapkan. Hal ini megandung implikasi bahwa internet banking harus mampu memberikan informasi dan penjelasan yang lebih kepada para nasabah agar nasabah yakin dan mau untuk memantapkan diri menggunakan internet banking sebagai alat transaksi yang dapat menghasilkan semua yang diinginkan para nasabahnya.

d. Kualitas Layanan yang baik akan memberikan nasabah kemudahan akan kejelasan produk yang ditawarkan oleh internet banking. Hal ini mengandung implikasi bahwa internet banking harus dapat memberikan informasi lebih detail dan rinci kepada nasabahnya supaya mereka lebih tertarik untuk menggunakan internet banking sebagai sarana bertransaksi yang praktis.

\section{Saran}

a. Mahasiswa bisa lebih mendalami atau menggunakan internet banking sebagai kegunaan bertransaksi karena lebih mudah dan efektif.

b. Kecemasan berkomputer dalam penelitian ini menghasilkan hubungan yang negatif terhadap Minat Menggunakan Internet Banking. Pada penelitian selanjutnya, peneliti diharapkan dapat lebih menjadikan materi dan bahan penelitian selanjutnya.

c. Mahasiswa tidak perlu meragukan dengan kejelasan informasi akan produkproduk yang ditawarkan internet banking.

d. Penelitian ini belum berdasarkan wawancara atau presepsi dari bank yang bersangkutan, pendapat hanya berdasarkan pengguna internet banking bank yang bersangkutan. Untuk penelitian selanjutnya, sebaiknya menambahkan persepsi dari pihak lain yaitu pihak bank selaku penyedia internet banking.

e. Penelitian ini menentukan jumlah sampel sebesar 139 yang merupakan jumlah minimum penentapan sampel sebuah penelitian. Sebaiknya penelitian selanjutnya lebih memperbanyak jumlah sampel yang ditentukan. 


\section{F. DAFTAR PUSTAKA}

Achmad, Solechan. (2010). Technology Acceptance Model (TAM). (Website http://solechanachmad.blogspot.com/2010/12/technology-acceptance-modeltam.html diakses 30 Mei 2012).

Aditya Fradana. (2011). Pengaruh Kualitas Sistem Informasi dan Perceived Usefulness terhadap Kepuasan Pengguna Software Akuntansi (Studi Kasus Mahasiswa Prodi Akuntansi Universitas Negeri Yogyakarta Angkatan 2007 dan 2008). Skripsi. Universitas Negeri Yogyakarta.

Ajzen Icek dan Fishbein, M. (1988). Attitudes, Personality, and Behavior. England: Open University Press \& Chicago

Amstrong, Gary \& Philip, Kotler. (2002). Dasar-dasar Pemasaran. Jilid 1, Alih. Bahasa Alexander Sindoro dan Benyamin Molan. Jakarta: Penerbit: Prenhalindo.

Bondan, Aditya (2011). Faktor-faktor yang Berpengaruh Terhadap Minat Nasabah Untuk Menggunakan Internet Banking di Magelang. Skripsi. Universitas Islam Indonesia.

Chanaka Jayawardhena, Paul Foley, (2000). "Changes in the Banking Sector - the Case of Internet Banking in the UK", Internet Research

Davis, Fred D., 1989. "Perceived Usefulness, Perceived Ease of Use, and User Aacceptance of Information Technology", MIS Quarterly.

Gilang Rizky Amijaya. (2010). Pengaruh Persepsi Teknologi Informasi, Kemudahan, Resiko Dan Fitur Layanan Terhadap Minat Ulang Nasabah Bank Dalam Menggunakan Internet Banking (Studi Pada Nasabah Bank BCA). Skripsi. Universitas Diponegoro Semarang.

Juniarti. (2001). Technolgy Acceptance Model (TAM) and Theory of Planned Behavior (TPB), Aplikasinya dalam Penggunaan Software Audit oleh Auditor. Jurnal Ekonomi dan Bisnis Indonesia.

Juwitahari. (2011). Trend Internet Banking. (Website http://blog.ub.ac.id/juwitahati/ 2011/03/28/internet-banking-trend-internet/diakses 16 April 2012).

Jogiyanto. (2005). Sistem Teknologi Informasi. Yogyakarta: Andi . (2007). Sistem Informasi Keperilakuan. Yogyakarta: Andi.

Joko Sulistyo. (2010). 6 Hari Jago SPSS 17. Yogyakarta: Cakrawala

Kotler, Philip. (2002). Manajemen Pemasaran di Indonesia : Analisis, Perencanaan, Implementasi dan Pengendalian. Jakarta: Salemba Empat. 
M. Suyanto. (2003). Strategi Periklanan Pada E-Commerce Perusahaan Top Dunia. Yogyakarta: Andi Offset.

Maharsi, Sri (2007). Faktor-faktor yang Mempengaruhi Minat Nasabah Menggunakan Internet Banking dengan Menggunakan Kerangka Technology Acceptance Model (TAM). Jurnal Universitas Kristen Petra Surabaya

Nur Indriantoro dan Bambang Supomo. (2009). Metodologi Penelitian Bisnis untuk Akuntansi dan Manajemen. Yogyakarta: BPFE.

Pasuraman, Igbaria (1998). Who's Affraid The Virtual World? Anxiety and ComputerMediated Communication.

Rofiq, Ainur. (2007). Pengaruh Dimensi Kepercayaan (Trust) terhadap Partisipasi Pelanggan E-Commerce (Studi Pada Pelanggan E-Commerce di Indonesia). (Website http://ubrawijaya.academia.edu/AinurRofiq/Papers/1031450/Pengaruh_Dimensi_Ke percayaan_Trust_Terhadap_Partisipasi_Pelanggan_e-

Commerce_Studi_Pada_Pelanggan_E-Commerce_di_Indonesia_diakses 20 Maret 2012).

Sugiyono. (2009). Metode Penelitian Kuantitatif Kualitatif dan R\&D. Bandung: Alfabeta.

Suharsimi Arikunto. (2006). Prosedur Penelitian Suatu Pendekatan Praktik. Jakarta: PT Adi Mahasatya.

Suhada. (2011). E-Banking. (Website http://suhanda666.wordpress.com/2011/05/25/ebanking/ diakses 16 April 2012).

Sukandarrumidi. (2006). Metodologi Penelitian. Yogyakarta: Gadjah Mada University Press.

Sutrisno Hadi. (2004). Analisis Regresi. Yogyakarta: Andi Offset.

Tim Penyusun Jurusan Pendidikan Akuntansi. (2007). Pedoman Penulisan Tugas Akhir Jurusan Pendidikan Akuntansi. Yogyakarta: Universitas Negeri Yogyakarta.

Tjiptono, Fandy. 2001. Strategi Pemasaran. Edisi Pertama. Yogyakarta: Andi Offset. . 2007. Strategi Pemasaran. Edisi Pertama. Yogyakarta: Andi Offset.

Turban dkk. (2005). Decision Support Systems and Intelligent Systems (Sistem Pendukung Keputusan dan Sistem Cerdas). Yogyakarta: Andi Offset

Williamson, Sharman (2006). Understanding Consumer Adoption of Internet Banking: An Interpretive Study in the Australian Banking Context. 